From the Department of Food Hygiene,

National Veterinary Institute, Helsinki, Finland.

\title{
Prevalence of Campylobacteria in the Finnish Broiler Chicken Chain from the Producer to the Consumer
}

\author{
By Matti Aho and Jorma Hirn
}

\begin{abstract}
Aho, M. and J. Hirn: Prevalence of campylobacteria in the Finnish broiler chicken chain from the producer to the consumer. Acta vet. scand. 1988, 29, 451-462. The prevalence of Campylobacter jejuni is $1.7 \%(9 / 600)$ in the faeces of $4-5$ week broiler chickens in Finland and $24 \%(117 / 490)$ in the caeci of broiler chickens at slaughter. All waste waters at a processing plant, except water in a chlorinated $(25$ ppm) chilling tank, contained campylobacteria when a campylobacter positive flock was slaughtered. Caeci contained mean $\log _{10} 7.2 \mathrm{CFU}$ campylobacteria/g. After chilling in a chlorinated ice-water tank there were still mean $\log _{10} 4.5 \mathrm{CFU}$ campylobacteria/carcass. Campylobacteria were detected from $7.0 \%(14 / 199)$ of deep-frozen broiler chicken carcasses at the market level. The concentration of C. jejuni in naturally contaminated deep-frozen broiler chicken carcasses decreased by $2 \log _{10}$ units in 4 weeks.

All prevalence figures were lower than in other developed countries outside Scandinavia. In Finland one of the reasons for low prevalence may be the extensive use of Nurmi cultures in Salmonella prevention programs.

food chain; contamination; food hygiene.
\end{abstract}

\section{Introduction}

The importance of Campylobacter jejuni and $C$. coli as common causes of human gastrointestinal disease is well documented. King (1962) proposed chickens as the primary source of human infection and Skirrow (1977) demonstrated an association in some cases between human disease and contact with chickens harboring the organism at farms, in butcher shops and in home kitchens. This association was later documented in several epidemiological studies (Severin 1978, Moulton et al. 1982, Harris 1986b). There are also several reports of outbreaks in which the epidemiologically implicated or suspected vehicle of campylobacteriosis has been raw, barbecued or undercooked chicken (Hayek \& Cruickshank
1977, Istre et al. 1984, Rosenfield et al. 1985). These outbreaks were with few exceptions of family size and without severe consequences. Only few epidemics among poultry abattoir workers have been reported (Christenson et al. 1983, Soto et al. 1986). In Finland Pönka et al. (1984) reported in an epidemiological study that $43 \%$ of 524 campylobacter enteritis outpatients during the years 1978-81 had contacted domestic campylobacteria, $59 \%$ of the patients had had contact with an animal and $28 \%$ had eaten poultry meat within a week before illness.

The prevalence of campylobacteria in chickens at slaughter has been examined in several studies (Table 1) and appears to be considerably lower in Scandinavia than in other developed countries. Previous studies (Geni- 
Table 1. Prevalence of campylobacteria in chickens at slaughter in different studies.

\begin{tabular}{|c|c|c|c|c|}
\hline $\begin{array}{l}\text { Region } \\
\text { Country }\end{array}$ & $\begin{array}{c}\text { Positive/ } \\
\text { all samples }\end{array}$ & $\%$ & Type of sample & Reference \\
\hline \multicolumn{5}{|l|}{ Scandinavia } \\
\hline Finland & $10 / 100$ & $10 \%$ & caecal contents & Hänninen \& Raevuori 1981 \\
\hline Sweden & $\begin{array}{c}18 / 50 \\
6 / 100\end{array}$ & $\begin{array}{r}36 \% \\
6 \%\end{array}$ & $\begin{array}{l}\text { faeces } \\
\text { faeces }\end{array}$ & Svedhem \& Kaijser 1981 \\
\hline Denmark & $223 / 396$ & $56 \%$ & caecal contents & Jørgensen 1982 \\
\hline Norway & $10 / 100^{\mathrm{a}}$ & $10 \%$ & pooled faeces & Rosef \& Kapperud 1982 \\
\hline Sweden & $8 / 16^{a}$ & $50 \%$ & $\begin{array}{l}\text { pooled caecal } \\
\text { contents }\end{array}$ & Engvall et al. 1986 \\
\hline \multicolumn{5}{|c|}{ Other developed countries } \\
\hline U.K. & $114 / 117$ & $68 \%$ & caecal contents & Bruce et al. 1977 \\
\hline Italy & $100 / 100$ & $100 \%$ & intestinal contents & Comi et al. 1984 \\
\hline F.R.G. & $98 / 120$ & $82 \%$ & caecal contents & Altmeyer et al. 1985 \\
\hline The Netherlands & $80 / 93$ & $86 \%$ & faeces & Bänffer 1985 \\
\hline U.S.A. & $117 / 247$ & $47 \%$ & intestinal contents & Harris et al. $1986 a$ \\
\hline \multicolumn{5}{|c|}{ Developing countries } \\
\hline South Africa & $26 / 30$ & $87 \%$ & faeces & Richardson \& Koornhof 1979 \\
\hline Brazil & $108 / 168$ & $64 \%$ & faeces & Levi \& Ricciardi 1982 \\
\hline Zaire & $14 / 36$ & $38 \%$ & intestinal contents & Damme \& Lauwers 1983 \\
\hline Chile & $\begin{array}{c}110 / 200 \\
25 / 26\end{array}$ & $\begin{array}{l}55 \% \\
96 \%\end{array}$ & $\begin{array}{l}\text { faeces } \\
\text { cloacal swab }\end{array}$ & Figueroa et al. 1983 \\
\hline Peru & $136 / 160$ & $85 \%$ & cloacal swab & Grados et al. 1983 \\
\hline
\end{tabular}

a positive flocks/all flocks examined

georgis et al. 1986, Hoop \& Ehrsam 1987) indicate that prevalence of campylobacteria in chicken increases with age. Some flocks may remain for long uninfected, but when the infection begins it spreads rapidly throughout the whole flock. Doyle (1984) suspected that climatic change may be one reason for increased isolation of $C$.jejuni from the feaces of laying hens. Vertical transmission is unlike to occur; Lindblom et al. (1986) found that environmental samples from the broiler chicken grow-out houses were negative, and only very few samples were positive at a time when most birds were campylobacter positive. By contrast Montrose et al. (1985) succeeded in infecting specific pathogen free (SPF) chickens by maintaining them on artificially contaminated litter. House flies have also been shown to be carriers of campylobacteria (Rosef \& Kapperud 1983, Wright 1983) and Shane et al. (1985) succeeded in infecting SPF chickens by allowing contaminated house flies to transmit campylobacteria. Shanker et al. (1986) found that the role of broiler chicken eggs in the transmission of $C$. jejuni to the grow-out flocks is minimal.

Variation between the results of studies concerning the prevalence of campylobacteria in broiler chickens sold fresh (Table 2) or deep-frozen (Table 3 ) is large, but again the results from Scandinavia appear to be at a lower level than in other developed countries. Although only a few quantitative studies are available, there is general agreement that fresh chicken carcasses may contain enough campylobacteria to cause infection in humans. 
Table 2. Prevalence of campylobacteria on the surface and in the meat of fresh broiler chickens in different studies.

\begin{tabular}{|c|c|c|c|c|c|}
\hline $\begin{array}{l}\text { Region } \\
\text { Country }\end{array}$ & Source & $\begin{array}{c}\text { Positive/ } \\
\text { all samples }\end{array}$ & $\%$ & $\begin{array}{l}\text { Type of } \\
\text { sample }\end{array}$ & Reference \\
\hline \multicolumn{6}{|l|}{ Scandinavia } \\
\hline Denmark & $\mathrm{Pa}^{\mathrm{a}}$ & $76 / 224$ & $34 \%$ & neck & Jorgensen 1982 \\
\hline Norway & $\begin{array}{l}\mathrm{P} \\
\mathrm{P}\end{array}$ & $\begin{array}{r}48 / 348 \\
151 / 313\end{array}$ & $\begin{array}{l}14 \% \\
48 \%\end{array}$ & $\begin{array}{l}\text { swab surface } \\
\text { swab surface }\end{array}$ & Rosef et al. 1984 \\
\hline \multicolumn{6}{|c|}{ Other developed countries } \\
\hline Australia & $\mathbf{P}$ & $18 / 40$ & $45 \%$ & carcass & Shanker et al. 1982 \\
\hline U.K. & $\mathbf{M}^{\mathrm{b}}$ & $30 / 38$ & $88 \%$ & surface & Dawkins et al. 1984 \\
\hline F.R.G. & $\begin{array}{l}\mathrm{P} \\
\mathrm{P} \\
\mathrm{P}\end{array}$ & $\begin{array}{c}26 / 30 \\
0 / 50 \\
145 / 180\end{array}$ & $\begin{array}{l}87 \% \\
81 \%\end{array}$ & $\begin{array}{l}\text { liver } \\
\text { meat } \\
\text { surface }\end{array}$ & Altmeyer et al. 1985 \\
\hline \multirow[t]{2}{*}{ Israel } & M & $53 / 127$ & $42 \%$ & $\begin{array}{l}\text { breast, heart, } \\
\text { neck, wing }\end{array}$ & Rogol et al. 1985 \\
\hline & $\mathbf{P}$ & $39 / 51$ & $77 \%$ & mixed parts & \\
\hline U.S.A. & M & $192 / 862$ & $22 \%$ & carcass & Harris et al. 1986a \\
\hline Switzerland & $\mathbf{P}$ & $206 / 660$ & $31 \%$ & skin & Hoop \& Ehrsam 1987 \\
\hline \multicolumn{6}{|c|}{ Developing countries } \\
\hline Brazil & $P$ & $179 / 227$ & $79 \%$ & carcass & Levi \& Ricciardi 1982 \\
\hline Chile & $P$ & $21 / 25$ & $84 \%$ & surface & Figueroa et al. 1983 \\
\hline
\end{tabular}

a sampling carried out at the processing plant

b sampling carried out at retail markets

Table 3. Prevalence of campylobacteria on the surface and in the meat of deep-frozen broiler chickens in different studies.

\begin{tabular}{|c|c|c|c|c|c|}
\hline $\begin{array}{l}\text { Region } \\
\text { Country }\end{array}$ & Source & $\begin{array}{l}\text { Positive/ } \\
\text { all samples }\end{array}$ & $\%$ & $\begin{array}{l}\text { Type of } \\
\text { sample }\end{array}$ & Reference \\
\hline \multicolumn{6}{|l|}{ Scandinavia } \\
\hline Denmark & $\mathrm{M}^{\mathrm{a}}$ & $9 / 23$ & $39 \%$ & melt-water & Rosef \& Bjorland 1981 \\
\hline Sweden & M & $6 / 10$ & & part of carcass & Svedhem et al. 1981 \\
\hline \multicolumn{6}{|c|}{ Other developed countries } \\
\hline The Netherlands & $\begin{array}{l}\mathbf{M} \\
\mathbf{M}\end{array}$ & & $\begin{array}{r}4 \% \\
36 \%\end{array}$ & $\begin{array}{l}\text { liver } \\
\text { carcass }\end{array}$ & Hartog \& Boer 1982 \\
\hline Hungary & $\mathbf{M}$ & $16 / 30$ & $53 \%$ & carcass & Marjai et al. 1982 \\
\hline \multirow[t]{2}{*}{ U.K. } & M & $18 / 60$ & $30 \%$ & \multirow{2}{*}{$\begin{array}{l}\text { inside of } \\
\text { carcass } \\
\text { giblets } \\
\text { melt-water }\end{array}$} & \multirow[t]{2}{*}{ Dawkins et al. 1984} \\
\hline & $\begin{array}{l}\mathrm{M} \\
\mathrm{M}\end{array}$ & $\begin{array}{l}23 / 56 \\
10 / 45\end{array}$ & $\begin{array}{l}41 \% \\
22 \%\end{array}$ & & \\
\hline U.K. Scotland & $\mathbf{M}$ & $177 / 198$ & $89 \%$ & giblets & Fricker 1984 \\
\hline U.S.A. & $\begin{array}{l}\mathrm{Pb}^{\mathrm{b}} \\
\mathrm{P}\end{array}$ & $\begin{array}{l}6 / 40 \\
0 / 40\end{array}$ & $15 \%$ & $\begin{array}{l}\text { liver } \\
\text { deboned meat }\end{array}$ & Stern et al. 1984 \\
\hline
\end{tabular}

a sampling carried out at retail markets

b sampling carried out at the processing plant 
During commercial processing intestinal bacteria contaminate the carcasses and widespread cross-contamination may take place (Oosterom et al. 1983). According to Wempe et al. (1983) the plucking machine and chilling tank were areas of major cross-contamination. Luechtefeld \& Wang (1981) reported that $34 \%$ of turkey carcasses which had been chilled in chlorinated (20-50 ppm) ice water were still positive for campylobacteria.

The present investigation was undertaken in 1985 to assess the prevalence of campylobacteria in the Finnish broiler chicken chain from the farm to the consumer and to make quantitative estimates of the contamination. Deep-frozen broiler chicken carcasses were chosen for the investigation because most broiler chicken carcasses are sold deepfrozen in Finland, although nowadays increasingly large numbers are sold fresh.

\section{Materials and methods}

\section{Transport and culture media}

SIFF medium for transport of faecal and caecal samples was prepared as described by Sandven et al. (1982). Transport media were portioned $10 \mathrm{ml}$ in screw-capped plastic test tubes and autoclaved for $20 \mathrm{~min}$ at $120^{\circ} \mathrm{C}$.

Skirrow broth and agar were prepared as described by Skirrow (1977) and Blaser et al. (1979) and modified by Hänninen (1981). The modification was addition $2 \mathrm{mg} / \mathrm{l}$ of amphotericin B (E. R. Squibb \& Sons Ltd., Liverpool, U.K.) to the media.

Alkaline tryptose broth (ATB) and brucella agar (ATB-agar) were prepared as described by Wesley et al. (1983).

Broths were portioned $90 \mathrm{ml}$ in $200 \mathrm{ml}$ flasks and agars $25 \mathrm{ml}$ on $\varnothing 9 \mathrm{~cm}$ Petri dishes with nodules. After inoculation, broths were incubated for $20 \mathrm{~h}$ and agars for $44 \mathrm{~h}$ at $43^{\circ} \mathrm{C}$ under a microaerophilic atmosphere achieved by evacuating gas boxes to -800 mbar and then filling them with a gas mixture containing $5 \% \mathrm{O}_{2}, 10 \% \mathrm{CO}_{2}$ and $85 \% \mathrm{~N}_{2}$. Evacuation and filling was carried out twice. Campylobacteria were recognized by examinating wet mounts by microscopy for curved rods exhibiting darting motility, by catalase and oxidase tests and by biotyping as described by Skirrow \& Benjamin (1980) with the modification of Lior (1984) to the $\mathrm{H}_{2} \mathrm{~S}$ test.

\section{Prevalence of campylobacteria in 4-5 week broiler chickens}

600 cloacal swabs were taken from 60 flocks at 55 different farms in southern Finland. Swabs were transferred immediately to SIFF medium for $1 \mathrm{~d}$ transport. In the laboratory, whole transport medium with the swab was enriched in Skirrow broth. Two loopfulls of incubated broth were plated on Skirrow agars.

\section{Prevalence of campylobacteria in broiler chickens at slaughter}

490 duplicate caecal swabs from 49 flocks grown out at 31 different farms in southern Finland were taken during the slaughtering process at 2 processing plants. Swabs were transferred immediately to SIFF medium for $1 \mathrm{~d}$ transport. In the laboratory $1 \mathrm{swab}$ with whole transport medium was enriched in Skirrow broth and the other with whole transport medium in ATB. Two loopfulls of incubated broths were plated on Skirrow and on ATB agars, respectively.

Cross-contamination in the processing plant Duplicate waste water samples $(200 \mathrm{ml})$ from 9 points at a processing plant (scald tank, plucking machine, evisceration machine, washing after evisceration, removing of lungs, last washing before chilling, first screw chilling tank, second screw chilling tank and third chilling tank, chlorinated 
with $25 \mathrm{ppm} \mathrm{Cl}_{2}$ ), 5 whole caeci and 5 carcasses ready for packaging were taken when a campylobacter positive (proven at the age of 4-5 weeks) flock entered the processing plant. $0.2 \mathrm{ml}$ of $10 \%$ sodium thiosulfate was added to the water samples from the third screw chilling tank. The capacity of the processing plant was 500 birds/h. Slaughtering was at maximal operation during sampling. Sampling was repeated three times. After 3 $\mathrm{h}$ chilled transport to the laboratory, quantitative examination of both waste water and caecum samples was carried out on Skirrow agars. Samples were diluted in $0.1 \%$ peptone water (BBL Microbiology Systems, Cockeysville, Md., U.S.A.) to give 10 fold dilutions. In addition, 1 and $10 \mathrm{ml}$ of the waste water samples were enriched in Skirrow broth and after incubation 2 loopfulls of broth were plated on Skirrow agars.

Quantitative examination of campylobacter surface contamination was carried out from 3 carcasses ( 1 bird from each of 3 samplings) by rinsing and maceration. Whole carcasses were put into plastic bags and $225 \mathrm{ml} 1 \%$ buffered peptone water (BBL) was added. The carcasses were macerated for $5 \mathrm{~min}$ by hand. The rinsing liquids were diluted in $0.1 \%$ peptone water (BBL) to give 10 fold dilutions and plated on Skirrow agar.

\section{Survival of campylobacteria in naturally contaminated chicken carcasses}

14 broiler chicken carcasses (4-5 from each sampling) were deep-frozen at $-18^{\circ} \mathrm{C}$ and stored up to 9 weeks. Thawing was carried out in a refrigerator at $6^{\circ} \mathrm{C}$ for $20 \mathrm{~h}$. Quantitative examination of campylobacteria on the surface of the carcasses was carried out weekly with the rinsing and maceration method as described above. In addition, $100 \mathrm{ml}$ of the rinsing liquid was pre-enriched for $5 \mathrm{~h}$ at $43^{\circ} \mathrm{C}$ under a microaerophilic atmosphere. $10 \mathrm{ml}$ of the pre-enriched liquid was enriched both in Skirrow broth and in ATB. After incubation, 2 loopfulls of the broths were plated both on Skirrow and on ATBagar, respectively.

Prevalence of campylobacteria in deepfrozen market broiler chicken carcasses

199 deep-frozen broiler chickens slaughtered at 3 different processing plants were purchased from retail markets in Helsinki. Thawing of the carcasses was carried out as described above. Qualitative investigation of campylobacter surface contamination was carried out by the rinsing and maceration method. $100 \mathrm{ml}$ of the rinsing liquid was pre-enriched for $5 \mathrm{~h}$ at $43^{\circ} \mathrm{C}$ under a microaerophilic atmosphere. $10 \mathrm{ml}$ of the preenriched liquid was enriched and plated as described above.

\section{Results}

The prevalence of campylobacteria in faeces of 4-5 week broiler chickens was $1.7 \%$ $(9 / 600)$. Isolations were from 3 flocks (Fig. 1). 8 of the isolates were $C$. jejuni biotype 1 and 1 was $C$. jejuni biotype 2 .

The prevalence of campylobacteria in caeci of broiler chickens at slaughter was $24 \%$ $(117 / 490)$ (Fig. 1). These isolates were from 13 flocks and 89 were $C$.jejuni biotype 1 and $28 \mathrm{C}$. jejuni biotype $2.78 \%$ were isolated with the ATB method and $85 \%$ with the Skirrow method. Contaminants were frequently observed on Skirrow agar. All the examples of $C$. jejuni biotype 2 were isolated from the carcasses supplied by a single processing plant. Only $12 / 28 C$. jejuni biotype 2 were isolated with the ATB method. One ATB method isolate was $\mathrm{H}_{2} \mathrm{~S}$ negative whereas the corresponding Skirrow method isolate was $\mathrm{H}_{2} \mathrm{~S}$ positive.

The prevalence of campylobacteria on the 


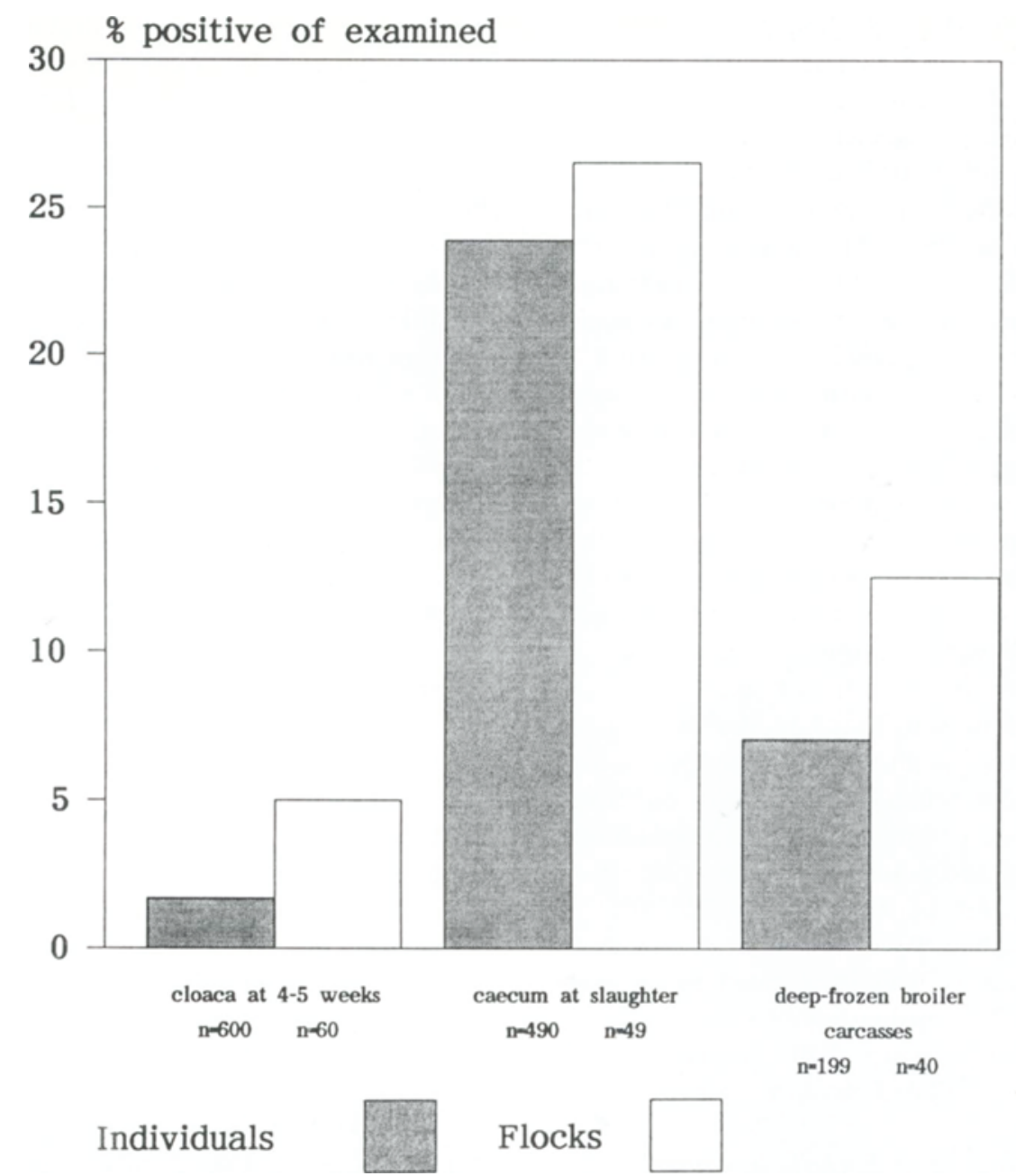

Figure 1. Prevalence of Campylobacter jejuni in broiler chickens and broiler chicken carcasses in Finland. Percentage of positive individuals and flocks out of all the individuals and flocks examined at the age of 4-5 weeks (cloacal swabs), at slaughter (caecal contents) and at the market level (deep-frozen broiler chickens, surface contamination investigated by the rinsing and maceration method). In the case of samples taken at the market level "flock" means 5 carcasses bought at a time and obtained from the same processing plant. See text for methods.

surface of deep-frozen broiler chicken carcasses at the market level was $7,0 \%$ $(14 / 199)$ (Fig. 1). Six of the isolates were C.jejuni biotype 1 and 8 were $C$.jejuni biotype 2. $2 / 14$ were isolated with the ATB method and 13/14 with the Skirrow method. All the $C$.jejuni biotype 2 isolates were supplied by the same processing plant as described above.

Results of the quantitative examination of 


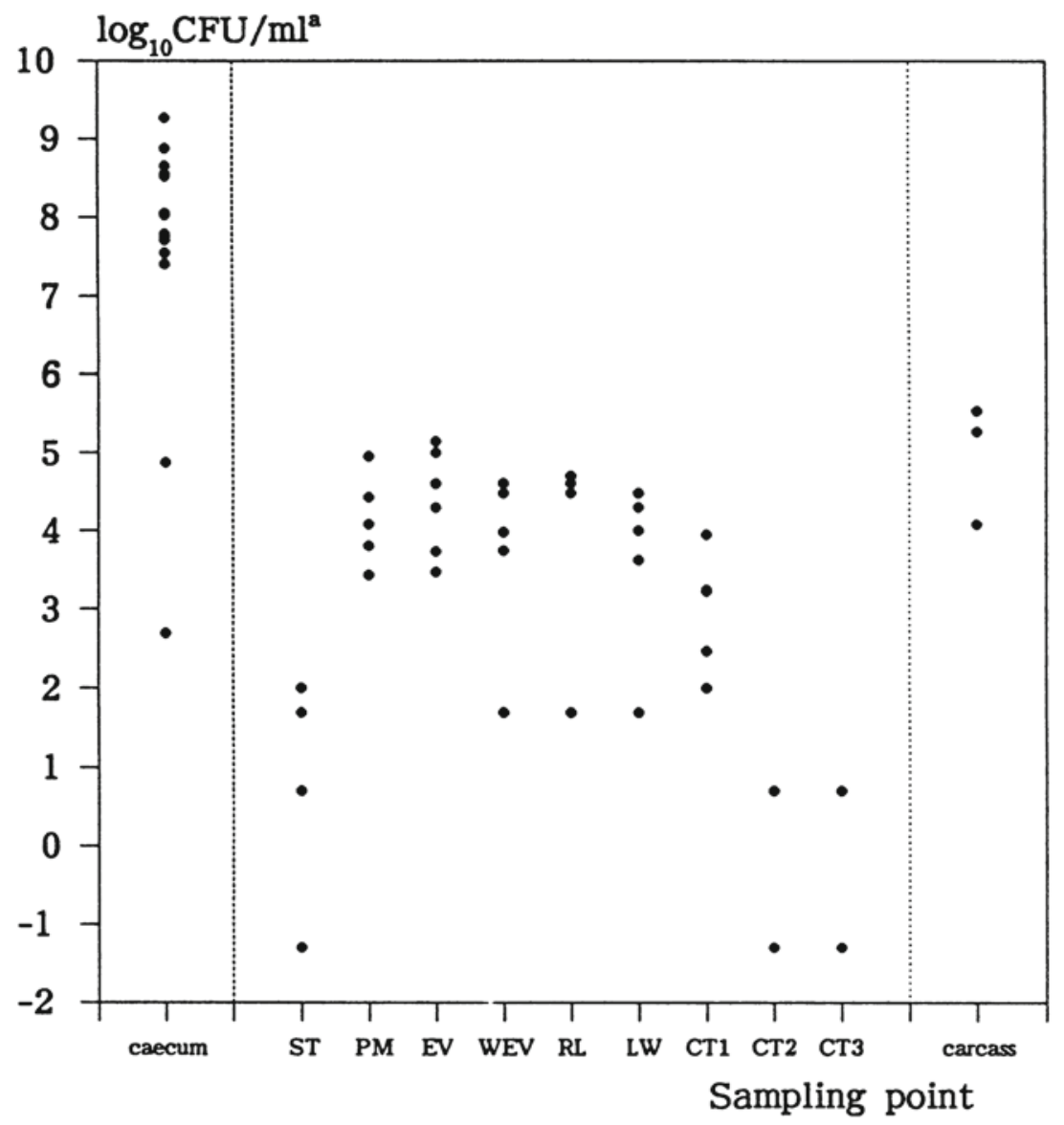

a Units change between squares.

Figure 2. Concentration of campylobacteria in caeci $\left(\log _{10} \mathrm{CFU} / \mathrm{g}\right)$, in duplicate waste water samples $\left(\log _{10} \mathrm{CFU} / \mathrm{ml}\right)$ and on the surface of broiler carcasses ready for packaging ( $\log _{10} \mathrm{CFU} /$ carcass) when a campylobacter positive flock (age 4-5 weeks) entered the processing plant. Three different flocks were analysed. For methods see text.

Sampling points ( $n=$ number of samples):

Units are in $\log _{10} \mathrm{CFU} / \mathrm{g}$ in the first block.

caecal contents $(n=15)$

Units are in $\log _{10} \mathrm{CFU} / \mathrm{ml}$ in the second block.

$\mathrm{ST}=$ scald tank $(n=0), \mathrm{PM}=$ plucking machine $(n=0), \mathrm{EV}=$ evisceration $(n=0), \mathrm{WEV}=$ washing after evisceration $(n=0), \mathrm{RL}=$ remocing of lugns $(n=0), \mathrm{LW}=$ last washing before chilling $(n=0), \mathrm{CT} 1=$ first chilling tank $(n=0), \mathrm{CT} 2=$ second chilling tank $(n=6)$, CT3=third chilling tank, chlorinated $(25 \mathrm{ppm})(n=0)$

Units are in $\log _{10} \mathrm{CFU} /$ carcass in the third block.

whole carcass $(n=3)$ 


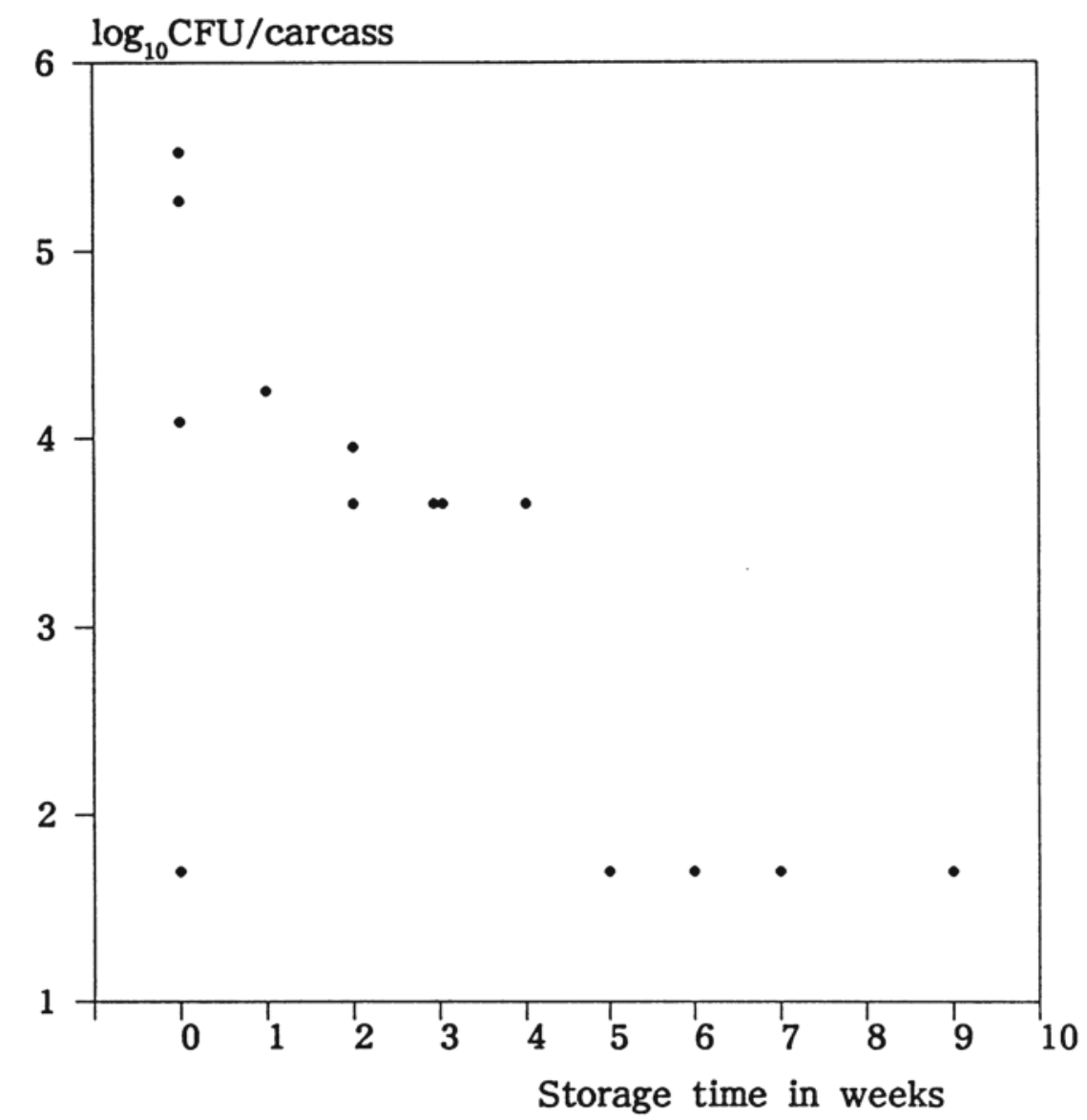

Figure 3. 14 broiler chicken carcasses from three flocks shown to be campylobacter positive (at the age of $4-5$ weeks) were stored at $-18^{\circ} \mathrm{C}$ for up to 9 weeks and examined weekly (except after 8 weeks) for campylobacteria by the rinsing and maceration method. Thawing was done in a refrigerator for $20 \mathrm{~h}$. Quantitative examination was carried out from the rinsing liquid on Skirrow agars. Qualitative examination was carried out by pre-enriching rinsing liquid for $5 \mathrm{~h}$ at $43^{\circ} \mathrm{C}$ under a microaerophilic atmosphere, by enriching the pre-enriched broth both on Skirrow broth and ATB and finally by plating the enriched broth on Skirrow and ATB agars, respectively. See text for details of the method. Qualitative results ( $1.70 \log _{10} \mathrm{CFU} /$ carcass) are shown in the figure only if quantitative results are lacking.

campylobacteria in caeci, in waste waters and in washing waters and screw chilling tank waters during slaughtering of a campylobacteria positive flock (proven at the age of 4-5 weeks) and on the surface of carcasses after processing are shown in Fig. 2.
Results of the quantitative and qualitative investigation of the survival campylobacteria on the surface of naturally contaminated broiler chicken carcasses at $-18^{\circ} \mathrm{C}$ are shown in Fig. 3. 


\section{Discussion}

Prevalence studies confirm that contamination of broiler chickens with campylobacteria is at a lower level in Finland than in other developed countries outside Scandinavia. Although seasonal variation could not be detected in this material it may represent the maximum, because the studies were carried out mostly in summer and autumn, at the time when campylobacteriosis is most prevalent among humans (Pönka et al. 1984). The widespread use of Nurmi cultures in preventing Salmonella infections among broiler chickens in Finland (Nurmi \& Rantala 1973) may be one explanation for this low prevalence (Soerjadi-Liem et al. 1983).

From the methodological point of wiev cloacal swabs are not a very efficient way of estimating prevalence. Campylobacteria are very sensitive to environmental conditions, secretion of campylobacteria may be intermittent and sampling could not be fully supervised at the farms. The sensitivity of our method is about 100 CFU campylobacteria/sample after $1 \mathrm{~d}$ transport at room temperature (unpublished).

According to Rosef et al. (1984) and Juven \& Rogol (1986) there is a wide variety of serotypes among isolates from single flocks of broiler chickens. Enrichment and plating methods may vary in their sensitivity of isolating different serotypes. Our few isolations of $C$. jejuni biotype 2 with the ATB method appear to support this assumption.

All waste water samples at the processing plant contained campylobacteria. Crosscontamination therefore occurs at the latest in the first 2 chilling tanks, which were not chlorinated. After chilling in the chlorinated screw chilling tank at $4^{\circ} \mathrm{C}$ there were still mean $\log _{10} 4.5 \mathrm{CFU}$ campylobacteria on the surface of fresh broiler chicken carcasses. Greater decrease in contamination could possibly be obtained by increasing the concentration of chlorine to 50-300 ppm (Luechtefeld \& Wang 1981) or by adding $0,1-1,0 \%$ acetic acid either to the scald tank (Okrend et al. 1986) or to the final chilling tank. Increase in the $\mathrm{pH}$ of the scald water has also been suggested (Hudson \& Mead 1987). These methods may possibly have an effect on the organoleptic quality of the carcasses. Cross-contamination during chilling can be avoided by chilling carcasses in an air chamber possibly also spraying carcasses with lactic acid.

Our studies on the survival of campylobacteria on the surface of deep-frozen broiler chicken carcasses agree rather well with previous studies both with artificial (Hänninen 1981) and natural contamination (Rosef et al. 1984). The concentration of campylobacteria on the surface of the carcasses decreased in four weeks by $2 \log _{10}$ units, after which campylobacteria could be detected only by sensitive methods.

\section{References}

Altmeyer von $M$, Krabish $P$, Dorn P: Occurrence and distribution of Campylobacter jejuni/coli in broiler production. 1. Communication. Dtsch. tierärztl. Wschr. 1985, 92, 456-459.

Blaser MJ, Hardesty HL, Powers B, Wang W$L L$ : Survival of Campylobacter fetus subsp. jejuni in biological milieus. J. Can. Microbiol. 1979, 11. 309-313.

Bruce D, Zochowski W, Ferguson IR: Campylobacter enteritis. Brit. Med. J. 1977, 2, 1219.

Bänffer JRJ: Biotypes and serotypes of Campylobacter jejuni and Campylobacter coli strains isolated from patients, pigs and chickens in the region of Rotterdam. J. Infect. 1985, 10, 277-281.

Christenson B, Ringner A, Blücher C, Billaudelle $H$, Gundtoft $K N$, Eriksson G, Böttiger M: An outbreak of campylobacter enteritis among the staff of a poultry abattoir in Sweden. Scand. J. infect. Dis. 1983, 15, 167-172. 
Comi G, Cantoni C, Marenda G: Campylobacter jejuni nelle carni di pollo. (Campylobacter jejuni in the meat of poultry). Arch. Vet. It. 1984, 35, 1-9.

Damme van LR, Lauwers $S$ : Isolation of Campylobacter jejuni from animals in Zaire. In: Pearson AD, Skirrow MB, Rowe B, Davies JR, Jones DM (eds.): Campylobacter II. Proceedings of the Second International Workshop on Campylobacter Infections, Brussels, 6.-9. September 1983, Public Health Laboratory Service, London 1983, p. 159.

Dawkins HC, Bolton JL, Hutchinson DN: A study of the spread of Campylobacter jejuni in four large kitchens. J. Hyg., Camb. 1984, 92, 357-364.

Doyle MP: Association of Campylobacter jejuni with laying hens and eggs. Appl. environ. Microbiol. 1984, 47, 533-536.

Engvall A, Bergqvist A, Sandstedt $K$, DanielssonTham $M-L$ : Colonisation of broilers with campylobacter in conventional broiler-chicken flocks. Acta vet. scand. 1986, 27, 450-457.

Figueroa $G$, Hidalgo $H$, Troncoso $M$, Rosende $S$, Soto V: Campylobacter jejuni in broilers, hens and eggs in a developing country. In: Pearson AD, Skirrow MB, Rowe B, Davies JR, Jones DM (eds.): Campylobacter II. Proceedings of the Second International Workshop on Campylobacter Infections, Brussels, 6.-9. September 1983. Public Health Laboratory Service, London 1983, pp. 161-162.

Fricker CR: Procedures for the isolation of Campylobacter jejuni and Campylobacter coli from poultry. Int. J. Food Microbiol. 1984, 1, 149154.

Genigeorgis C, Hassuneh M, Collins P: Campylobacter jejuni infection on poultry farms and its effect on poultry meat contamination during slaughtering. J. Food Prot. 1986, 49, 895903.

Grados O, Bravo N, Butzler JP, Ventura G: Campylobacter infection: an occupational disease risk in chicken handlers. In: Pearson $A D$, Skirrow MB, Rowe B, Davies JR, Jones DM (eds.): Campylobacter II. Proceedings of the Second International Workshop on Campylobacter Infections, Brussels, 6.-9. September
1983. Public Health Laboratory Service, London 1983, p. 162.

Harris $N V$, Thompson D, Martin DC, Nolan CM: A survey of Campylobacter and other bacterial contaminants of pre-market chicken and retail poultry and meats, King county, Washington. Amer. J. Publ. Hlth 1986a, 76, 401406.

Harris NV, Weiss NS, Nolan CM: The role of poultry and meats in the etiology of Campylobacter jejuni/coli enteritis. Amer. J. Publ. Hlth 1986b, 76, 407-411.

Hartog BJ, Boer de E: Campylobacter jejuni in poultry products from retail outlets and in poultry slaughterhouses. In: Newell DG (ed.): Campylobacter. Epidemiology, Pathogenesis and Biochemistry. MTP Press Limited, Lancaster 1982, p. 270.

Hayek LJ, Cruickshank JG: Campylobacter enteritis. Brit. Med. J. 1977, 2, 1219.

Hoop R, Ehrsam H: Ein Beitrag zur Epidemiologie von Campylobacter jejuni und Campylobacter coli in der Hühnermast. (On the epidemiology of Campylobacter jejuni and Campylobacter coli in the broiler chicken production). Schweiz. Arch. Tierheilkd. 1987, 129, 193-203.

Hudson WR, Mead GC: Factors affecting the survival of Campylobacter jejuni in relation to immersion scalding of poultry. Vet. Rec. 1987, $121,225-227$.

Hänninen $M-L$ : Survival of Campylobacter jejuni/coli in ground refrigerated and ground frozen beef liver and in frozen broiler carcasses. Acta vet. scand. 1981, 22, 566-577.

Hänninen M-L, Raevuori M: Occurrence of Campylobacter fetus subsp. jejuni and Yersinia enterocolitica in domestic animals and in some foods of animal origin in Finland. Nord. Vet.-Med. 1981, 33, 441-445.

Istre GR, Blaser MJ, Shillam P, Hopkins RS: Campylobacter enteritis associated with undercooked barbecued chicken. Amer. J. Publ. Hlth. 1984, 74, 1265-1267.

Juven BJ, Rogol M: Incidence of Campylobacter jejuni and Campylobacter coli serogroups in chicken processing factory. J. Food Prot. 1986, 49, 290-292. 
Jorgensen, $K$ : De mulige relationer mellem forekomst af Campylobacter jejuni i fjerkræ og levnedsmidler og human campylobacteriose. (The possible relationship between human campylobacteriosis and the occurrence of Campylobacter jejuni in poultry and in foodstuffs). In: Proceedings of XIV Nordiske Veterinaerkongress, København, 5.-9. June 1982, pp. 223-224.

King EO: The laboratory recognition of Vibrio fetus and closely related Vibrio isolated from cases of human vibriosis. Ann. N. Y. Acad. Sci. 1962, 98, 700-711.

Levi A, Ricciardi ID: Campylobacter fetus subsp. jejuni (C. jejuni): Identification of strains isolated from chickens in Rio de Janeiro. Rev. Microbiol., Sao Paulo, 1982, 13, 332-334.

Lindblom G-B, Sjögren E, Kaijser B: Natural campylobacter colonization in chickens raised under different environmental conditions. J. Hyg., Camb. 1986, 96, 385-391.

Lior H: New, extended biotyping scheme for Campylobacter jejuni, Campylobacter coli, and "Campylobacter laridis". J. clin. Microbiol. 1984, 20, 636-640.

Luechtefeld NW, Wang W-LL: Campylobacter fetus subsp. jejuni in a turkey processing plant. J. clin. Microbiol. 1981, 13, 226-228.

Marjai E, Kováts Z, Kajáry I, Horváth Z: Campylobacter jejuni contamination of slaughtered chickens. Acta Microbiol. Acad. Sci. Hung. 1982, 29, 213-215.

Montrose MS, Shane SM, Harrington KS: Role of litter in the transmission of Campylobacter jejuni. Avian Dis. 1985, 29, 392-399.

Moulton RP, Veltkamp JJ, Lauwers S, Butzler $J P$ : Analysis of small outbreak of campylobacter infections with high morbidity. In: Newell DG (ed.): campylobacter. Epidemiology, Pathogenesis and Biochemistry. MTP Press Limited, Lancaster 1982, pp. 129-134.

Nurmi E, Rantala M: New aspects of Salmonella infection in broiler production. Nature 1973, 241, 210-211.

Okrend AJ, Johnston $R V$, Moran $A B$ : Effect of acetic acid on the death rate at $52^{\circ} \mathrm{C}$ of $\mathrm{Sal}$ monella typhimurium and Campylobacter jejuni in poultry scald water. J. Food Prot. 1986, 49, 500-503.
Oosterom J, Wilde de GJA, Boer de E, Blaauw de LH, Karman H: Survival of Campylobacter jejuni during poultry processing and pig slaughtering. J. Food Prot. 1983, 46, 702-706.

Pönka A, Pitkänen T, Sarna S, Kosunen TU: Infection due to Campylobacter jejuni: a report of 524 outpatients. J. Infect. 1984, 12, 175178.

Richardson NJ, Koornhof HJ: Campylobacter infections in Soweto. S. Afr. Med. J. 1979, 54, 73-74.

Rogol M, Sechter I, Greenberg Z, Mizrachi R, Shtark $Y$, Alfi $S$ : Contamination of chicken meat and environment with various serogroups of Campylobacter jejuni/coli. Int. J. Food Microbiol. 1985, 1, 271-276.

Rosef $O$, Bjorland J: Forekomsten av Campylobacter fetus subsp. jejuni i importerte frosne fjørfe og småvilt. (Occurrence of Campylobacter fetus subsp. jejuni in imported deep-frozen poultry and small game). Norsk Veterinaertidsskrift 1981, 93, 689-692.

Rosef $O$, Kapperud $G$ : Isolation of Campylobacter fetus subsp. jejuni from faeces of Norwegian poultry. Acta vet. scand. 1982, 23, 128-134.

Rosef $O$, Kapperud $G$ : House flies (Musca domestica) as possible vectors of Campylobacter fetus subsp. jejuni. Appl. environ. Microbiol. 1983, 45, 381-383.

Rosef O, Gondrosen B, Kapperud G: Campylobacter jejuni and Campylobacter coli as surface contaminants of fresh and frozen poultry carcasses. Int. J. Food Microbiol. 1984, 1, 205215.

Rosenfield JA, Arnold GJ, Davey GR, Archer RS, Woods WH: Serotyping of Campylobacter jejuni from an outbreak of enteritis implicating chicken. J. Infect. 1985, 11, 159-165.

Sandven $P$, Solberg $O$, Ødegaard K, Myhre G: Improved medium for the transportation of gonococcal specimens. Acta pathol. microbiol. immunol. Scand. sect. B. 1982, 90, 73-77.

Severin WPJ: Campylobacter and enteritis. Ned. T. Geneesk. 1978, 122, 499-504.

Shane SM, Montrose MS, Harrington KS: Transmission of Campylobacter jejuni by the housefly (Musca domestica). Avian Dis. 1985, 29, 384-391. 
Shanker S, Rosenfield JA, Davey GR, Sorrell TC: Campylobacter jejuni: incidence in processed broilers and biotype distribution in human and broiler isolates. Appl. environ. Microbiol. 1982, 43, 1219-1220.

Shanker S, Lee A, Sorrell TC: Campylobacter jejuni in broilers: the role of vertical transmission. J. Hyg., Camb. 1986, 96, 153-159.

Skirrow MB: Campylobacter enteritis: a "new" disease. Brit. Med. J. 1977, 2, 9-11.

Skirrow MB, Benjamin J: Differentiation of enteropathogenic campylobacter. J. clin. Pathol. 1980, 33, 1122.

Soerjadi-Liem AS, Snoeyenbos GH, Weinack $O M$ : Comparative studies on competitive exclusion of three isolates of Campylobacter fetus subsp. jejuni in chickens by native gut microflora. Avian Dis. 1983, 28, 139-146.

Soto A, Figueroa G, Urcelay $S$ : Frequency of infection with Campylobacter jejuni/coli and the occurrence of IgG, IgM and complement fixing antibodies against the agent in workers in poultry abattoir in Santiago, Chile. J. Vet. Med. B 1986, 33, 676-684.

Stern NJ, Green SS, Thaker N, Krout DJ, Chiu J: Recovery of Campylobacter jejuni from fresh and frozen meat and poultry collected at slaughter. J. Food Prot. 1984, 47, 372-374.

Svedhem A, Kaijser B: Isolation of Campylobacter jejuni from domestic animals and pets: probable origin of human infection. J. Infect. 1981, 3, 37-40.

Svedhem A, Kaijser B, Sjögren E: The occurrence of Campylobacter jejuni in fresh food and survival under different conditions. J. Hyg., Camb. 1981, 87, 421-425.
Wempe JM, Genigeorgis GA, Farver TB, Yusufu HI: Prevalence of Campylobacter jejuni in two California chicken processing plants. Appl. environ. Microbiol. 1983, 45, 355-359. Wesley RD, Swaminathan B, Stadelman WJ: Isolation and enumeration of Campylobacter jejuni from poultry products by selective enrichment method. Appl. environ. Microbiol. 1983, 46, 1097-1102.

Wright EP: The isolation of Campylobacter jejuni from flies. J. Hyg., Camb. 1983, 91, 223 -226 .

\section{Sammanfattning}

Prevalens av campylobakterier $i$ broiler kedjen från producenten till konsumenten $i$ Finland.

Prevalensen av Campylobacter jejuni i Finland är $1.7 \%(9 / 600)$ i avföring av 4-5 veckor gamla broilers och $24 \%(117 / 490)$ i caeci vid slakten. Alla avfallsvattenprov, med ett undantag av en klorerad avkylningstank ( $25 \mathrm{ppm})$, i produktionsinrättning innehöll campylobakterier när en campylobakterpositiv flock slaktades. Caeci innehöll $\log _{10}$ 7.2 CFU campylobakterier/g (medelvärde). Efter avkylning $i$ en klorerad isvattentank kunde $\log _{10}$ 4.5 CFU campylobakterier isoleras från en kropp (medelvärde). På handelsnivå isolerades campylobakterier ur $7.0 \%(14 / 199)$ av djupfrysta broilers. Förekomsten av campylobakterier hos naturligt kontaminerade djupfrysta broilers efter fyra veckors förvaring $\mathrm{i}-18^{\circ} \mathrm{C}$ var $2 \log _{10}$ enheter lägre än hos kropparna strax efter slaktningen.

Alla prevalensvärden är mindre än i andra utvecklade länder med undantag av de skandinaviska länderna, kanske för att Nurmi kulturer användes allmänt för att bekämpa Salmonella i Finland.

(Received April 15, 1988).

Reprints may be requested from: Matti Aho, National Veterinary Institute, P. O. Box 368, SF-00101 Helsinki, Finland. 